\title{
THE EFFECT OF WORD WALL MEDIA ON WRITING ACHIEVEMENT OF THE SEVENTH GRADE STUDENTS OF SMP NEGERI 1 SERIRIT IN ACADEMIC YEAR 2018/2019
}

\author{
I.G. A. L. Sawitri', Sudirman², A. A. G. Y. Paramartha ${ }^{3}$ \\ English Language Education \\ Ganesha University of Education \\ Singaraja, Indonesia \\ gusti.ayu.laksmi@undiksha.ac.id, sudirman@undiksha.ac.id, yudha.paramartha@undiksha.ac.id
}

\begin{abstract}
Abstrak
Penelitian ini bertujuan untuk mengetahui pengaruh penggunaan media word wall terhadap prestasi menulis pada siswa kelas VII SMP N 1 Seririt. Desain penelitian ini adalah Quasi Experimental desain Post-Test Only Control Group yang melibatkan murid kelas VII SMP N 1 Seririt. Cluster random sampling digunakan untuk memilih sampel penelitian di mana kelas VII F menjadi kelompok eksperimen dengan menggunakan media word wall. Hasil analisis data menunjukkan terdapat pengaruh terhadap prestasi menulis siswa antara siswa yang diajar dengan menggunakan media word wall dan siswa yang tidak. Selain itu, hasil ukuran dalam penelitian ini adalah 0,56 yang menunjukkan bahwa media word wall memberikan pengaruh pada prestasi menulis siswa. Dapat disimpulkan bahwa kegiatan menulis dengan menggunakan media word wall dapat memberikan pengaruh terhadap prestasi menulis siswa.
\end{abstract}

Kata kunci: media, word wall, prestasi menulis

\section{Abstract}

This study aimed at investigating the effect of using word wall media on writing achievement of the seventh grade students of SMP N 1 Seririt. The research design was Quasi Experimental of PostTest Only Control Group design taking the seventh grade students of SMP N 1 Seririt. On the other hand, VII $D$ as the control group was treated by using conventional media without word wall. The result of data analysis shows that there is a significant effect on students' writing achievement between students from the experimental group and those from the control group ( $t=8.826, d f=62, p<$ 0.05). Moreover, the result of effect size in this study was 0.56 which indicates that word wall media give a strong influence on students' writing achievement. Referring to those results, it can be concluded that writing activities by using word wall media can give significant effect on students' writing achievement.

Keywords: word wall, media, writing achievement 


\section{INTRODUCTION}

By looking at the fact that English is a global language with various benefits, Indonesia as one of the EFL countries also takes English as an important subject that should be taught at school. In formal school, students in Indonesia have been learning English since elementary school which means the students have known English since early age. Generally speaking, students are supposed to develop four essential skills namely listening, speaking, reading and writing in order to master the language well. Based on the latest curriculum of teaching English in Indonesia especially for seventh grade students, one of the basic competences in learning the language is that the students are able to create a text in form of descriptive text, announcement text, recount text, and narrative. This capability can be gained by developing the students' writing skill through writing activity. Writing is one of the four main skills that foreign language students need to develop in order to learn the language successfully. Writing is the written expression of thoughts, desires, emotions, and schemes; and this requires skill rather than knowledge $(\mathrm{Oz}, 2006: 251)$. Writing is a skill to make coherent words on paper to compose a paragraph or text. Developing written skills will enable students to learn how to compose ideas and share information. Acquiring this skill will also prepare students for their future academic and professional career. But there are times when writing seems to be complicated to do. According to Fauziati (2015:123), indeed it is generally argued that writing is the most difficult skill to be mastered among other types of language skills. Even in a book entitled "Writing Academic English", Oshima and Hogue (1983:79) have mentioned that writing is the most difficult part to start. This is because writing is not just copying words and sentences, but also developing and pouring thoughts in a writing structure (Fauziati, 2015:123). Bell \& Burnaby (as cited inNunan, 1989:74) also stated that the complexity of writing is due to the high cognitive activity which required by a writer to "demonstrate and control the variables simultaneously". Writing also needs a process which requires both grammar and good organization (Oshima\& Hogue, 1983:1), so it requires precision to be able to structure and integrate information into coherent paragraphs and text.

As a complicated skill, writing has some difficulties that usually occur in writing activities. According to a study which deals with the difficulty of writing by Khotimah \& Suryandari (2015:495), there are some difficulties that occur during writing activities. Those are the difficulty in determining the title based on the given theme, the difficulty in taking the main idea, and the difficulty in developing the paragraph. Still, according to Khotimah \& Suryandari (2015:498), the difficulties are caused by an inability to convey the existing ideas. It can also be caused by a misunderstanding about the theme as well as a low cognitive development. To overcome that matters a concrete media will be required to help them put out the ideas into a form of writing. A concrete media here is a visual tool to facilitate teacher in conveying the material. As Sari \& Sari (2015:28) said, using media to study is a best solution to make students grasp what is given by the teacher quickly. For those stated reasons, Word Wall media is introduced as one of the media to enhance students in learning English especially in writing.

Word Wall is an interactive ongoing display such as on a chart, bulletin board, or another exhibition medium (Cronsberry, 2004:3). These words are continually referred in every activity that students and teachers do in the class (Cronsberry, 2004:3). According to Galih (as cited in Kasim, 2013:22), this media is designed to be an interactive tool for students and contained some references that can be used during writing. It will reinforce 
them to learn over and over in the classroom. They can practice some new words each day by looking at it, saying, clapping, chanting, snapping the letters, writing the words on paper, and self-correcting the words with the teacher (Hall \& Cunningham as cited in Jasmine \&Schiesl, 2009:4).

According to Widikasih (2008:14), Word Wall has some advantages. 1) It will support students' vocabulary and spelling development which can help them in writing activity. 2) It contains reference which supports their writing during the English classes. This advantage will help students who have difficulty in conveying their ideas in writing. 3) This media can also help students in developing paragraphs because Word Wall is organized based on ideas related to the given theme. 4) It also provides many activities that allow students to practice in writing instantly and automatically.

Word Wall as media is often used as a method in several related studies, such as by Kurniasih, Regina, \&Arifin (2015:4) on The Use of Word Wall Media in Teaching Descriptive Writing. The research took place in one of the high schools in Pontianak, Kalimantan. The purpose of this research is to find the effect of using Word Wall Media in descriptive writing study. The next research is conducted in Bali, precisely in Gianyar Regency by Indrayana (2014:5). The research entitled The Use of Word Wall Game to Teach Writing Skill of the Eight Grade Students. The result of both researchers above is the effect of using Word Wall media makes the students able to get high score compare with students who did not get Word Wall media in classroom learning. Although some studies state that this media is great for writing activities, there is no evidence to show the effectiveness of Word Wall in Seririt District, especially in SMP N 1 Seririt. That is why this research is intended to confirm whether Word Wall Media also has a positive influence in Seririt or not.

This research needs to be conducted to find out what media is appropriate to overcome the problem that usually made by students in writing. Other than that, this research will help the teacher to implement the appropriate learning media in the class. Considering those reasons, the researcher is interested in knowing the effect of implementing Word Wall media in writing.

\section{METHOD}

This research was conducted in SMP Negeri 1 Seririt, which is located at Udayana Street, No. 25 A, Seririt, Buleleng, Bali. Based on some considerations, this school is appropriate for conducting a research. A preliminary observation was done to get information about the seventh grade students at the first semester in academic years 2018/2019. Based on the observation, it was found that the number of the seventh grade students of SMP Negeri 1 Seririt consist of 224 students. They are divided into 7 classes namely VII A until VII $G$ which consist of 32 students in every class.

This research was designed in a quasi-experimental one. According to Tuckman (1999:168), quasi-experimental is effective to be employed in a certain condition which prevents the researcher to complete the experimental control. Specifically, post-test only control group design had been chosen to run this research which needed two groups of students as samples. Those groups are the experimental group and the control group. The 
experimental group would be given the treatment of Word Wall media while the control group would not.

In this type of design, only the score of the post-test result would be analyzed in the data analysis. Moreover, the score used in normality and homogeneity test of variance was the score of students from the previous test before the treatment namely summative score. The summative test was already conducted by the English teacher of the experimental and control group to find out the groups' scores. After conducting the treatment, the post-test was conducted to each group and the result was measured to find out whether or not there was a significant effect by implementing Word Wall Media on writing achievement of seventh grade students in SMP Negeri 1 Seririt.

The population of this research was the seventh grade students of SMP Negeri 1 Seririt who were learning English as a foreign language in academic year 2018/2019, especially from the first semester. There are seven classes of seventh grade which consists of 224 students. The class starts from VII A until VII G.After collecting the data, the next step is to analyze the data that have been collected. The data is analyzed by using two forms of statistical analysis, they are: descriptive statistics and inferential statistics analysis.

\section{FINDING AND DISCUSSION}

In this study, the descriptive statistical analysis provides information about the findings of the measures of central tendency such as mean, median, and measures of dispersion such as range, variance, standard deviation, and mode of writing achievement post-test. The data description of the post-test result from both control and experimental group was analyzed using IBM Statistics SPSS 17. The result of the descriptive analysis can be seen on the table below:

\begin{tabular}{lrr} 
Statistics & $\begin{array}{r}\text { Table 1.1 The Result of Descriptive Analysis of Post-Test Score } \\
\text { Control } \\
\text { Group }\end{array}$ & $\begin{array}{c}\text { Experimental } \\
\text { Group }\end{array}$ \\
\hline N & 32 & 32 \\
Min. & 47.50 & 54.38 \\
Max. & 69.69 & 91.56 \\
Mean & 57.92 & 73.38
\end{tabular}

Mean refers to the sum of scores in a distribution devided by number of the distribution. Mean score in this study was obtained by the two groups at the end of the session. The table 4.2 above shows that the mean score of the experimental group was higher than the mean score of the control group. The mean score of the experimental group was 73.38 and the mean score of the control group was 57.92.

To know the differences between the classes, Independent Sample t-test was used since this study compared the means of two randomly assigned sample groups, namely experimental group (treated by using Word Wall media) and control group (treated without using Word Wall). The result of the Independent Sample t-test can be seen in table below.

Table 1.2 The Result of Independent Sample T-Test

\begin{tabular}{lrr} 
& Statistics & Value \\
\hline $\mathrm{T}$ & 8.826 \\
Df & 62
\end{tabular}


Sig.

.000

Besides the descriptive and inferential statistics analysis, the researcher also used effect size calculation to measure the treatment effect. The result of the effect size showed below on figure 1.1 was 0.56 . It can be categorize as large effect. It means that teaching by using word wall media gave a large effect on students' writing achievement.

$$
\begin{aligned}
& \frac{t^{2}}{t^{2}+(N 1+N 2-2)} \\
& \frac{8.826^{2}}{8.826^{2}+62}=\frac{77.898}{139.898}=0.56
\end{aligned}
$$

Figure 1.1 Effect Size

From the data analysis above, it was found that the word wall media gave significant effect to the students' on their writing achievement. The result of this study showed that the students who were taught by using Word Wall Media had better achievement than the students who were taught by using conventional media. In terms of descriptive statistical analysis, the result of their post-test score or the mean score of the experimental group was higher than the control group scores. The mean score of the experimental group was 73.38 and the mean score of the control group was 57.50. Moreover the result of inferential statistical analysis showed that the value of sig.(two tailed) was 0.000 which indicates there was a significant effect of word wall media towards the students' writing scores at seventh graders of SMP N 1 Seririt and the null hypothesis was rejected.

There were different responses towards the lesson and the activity. In the control group, the students were working only at first and second meeting. It can't be written easily. When started to write, some of the students did not pay attention to their friends when their friends tried to plan out ideas for writing. In contrast, the experimental students were more excited to enjoy writing activity in the classroom. It could be seen through their excitement when they were able to make writing. Further, with the writing activity since every time they have to write a paragraph, it would be challenging for them to make the right one. The results of this study are also in line with those found by Kurniasih, et al (2015: 19), namely when the study was conducted, students from the experimental class looked more active while students in the control class would only respond if they were asked questions. This was also seen when the post-tests took place, experimental classes tended to be more enthusiastic when writing and sorting out their ideas. Indrayana (2014: 13) reveals, students will tend to be quiet and less enthusiastic if an activity is considered difficult to do. Another reason was also stated by Kurniasih, et al (2015: 20) that the absence of appropriate media can make students bored faster so that they tend to be passive and their lack of curiosity towards activities in the classroom.

Not only in response to the activities carried out, the differences seen from the two classes lies in the content of their post-test results. In this study, the results of the post-test obtained from the experimental class looked more varied and had more complete content. But on the contrary, in the control class the writing that is made tends to only follow the example given by the teacher. Sari \& Sari (2015: 28) confirmed the results obtained that the 
writing made by experimental class students was varied because it was easier for them to access information from the Word Wall provided. Apart from being more varied, students who are in the experiment class look easier and faster in finding their ideas in writing. Of course this is due to the presence of Word Wall as a tool to support them to get information quickly and accurately (Galih, 2013: 22). Sari \& Sari (2015: 12) also explained the word wall media deliberately designed by having several references that students could use to write. When students in the experiment class start writing, they did the scanning process by looking for what can be used to make ideas in their writing activities.

Furthermore, students in the experiment class did not seem difficult to find vocabularies related to their writing ideas. This is because of the references available around them (Sari \& Sari, 2015:12) so they were able to quickly chose the words printed on the word wall option. This had also been stated by Widikasih (2008: 14) the word wall media can support students to get new vocabularies and can improve the development of their spelling of new words. Although both classes are beginners in English lessons, what happens in the control class is the opposite. Students in the control class seemed more confused in choosing words because they did not have maximum references. They tend to ask teachers more often about vocabularies in English because of the lack of references around them.

From some of the findings mentioned above, it can be concluded that the two classes have significant differences. The difference lies in their response to activities carried out in class. Although the two classes warmly welcomed the material taught, the experiment class looked more enthusiastic than the control class. Also seen when the writing process is done, the control class is more likely to be quiet and easily bored. Other differences can be seen from how quickly they work on the writing and how complete the content is in their writing. As said by Galih (2013: 22), with the word wall makes it easy for them to get information quickly and accurately. This is evident in the findings of this study, namely that the writing content of students in the experimental class is more complete and the process is fast. Furthermore, the vocabulary on the writing content of the experimental class students is more varied so making the word wall is the best solution to the problem of writing (Sari \& Sari, 2015: 28). That is the result of the discovery that can be used as a comparison so that the word wall is a good medium for writing thus "writing is often considered as the most difficult language skill to be learnt" (Paramartha, 2012: 1).

\section{LIMITATION}

When conducting this research, there were some limitations appeared. The first limitation lies on the word wall media used. In the application of word wall media, this research uses media from paper which tend to be more easily damaged and wet. This is very detrimental because the word wall must remain good so that it can be used for other activities such as games and others. So that for further research it is expected to use cartons, styrofoam, or laminate paper used for media. The next problem is because the word wall is permanent media and in this research, word wall used for other themes. Besides that, there is also a technical problem that the obstacles in using the word wall in the class, that is, the class used for treatment is not a permanent class so the attached word wall must be restored when they come home so as not to pollute the class from the original class owner. Those are the limitations which should be considered to be further as recommendation for further research to conduct.

\section{CONCLUSION AND SUGGESTION}


By looking at the result of descriptive and inferential statistical analysis that had been presented previously, it could be concluded that the use of Word Wall media for teaching writing of the seventh-grade students gave significant effect on students' writing achievement. It could be shown through the statistical analysis in which it was found that the mean score of students' writing achievement in the experimental group was higher than the mean score of the students in the control group. It indicated that the writing achievement of the students in the experimental group was better compared to the mean score of students in the control group.

Moreover, the inferential statistical analysis also showed that the value of t-observed (tobs) was higher than the value of $t$-critical value (tcv). The comparison between tobs and tcv was indicated that the alternative hypothesis was accepted. Then, it could be concluded that they were was a significant effect on the students' writing achievement between the students who were taught by using Word Wall media and the students who were taught by using conventional media in SMP Negeri 1 Seririt in academic year 2018/2019.

In connection to the result of the research, there are some suggestions that can be proposed by the researcher as the following:

- $\quad$ For the Teacher

It is recommended for the English teachers to use Word Wall in writing activity. It is because Word Wall will require the students to write down their outline and have their framework of writing without any doubt. Word Wall will lead the students to find out the path in doing their writing.

- $\quad$ For the students

It is also recommended for the students to make their own Word Wall on their house-wall so they can practice every day.

- $\quad$ For other Researchers

Since this study is limited to the descriptive text, it is suggested to conduct the similar research with a different topic in writing or with the general topic so that the result can be more generalized.

\section{REFERENCES}

Bayu, IG.B.C.,dkk. 2018.The Effect of "Storytelling Using Puppet" Strategy on Students'speaking Achievement At Eighth Grade Of Junior High School In SMP Negeri 1 Seririt. International Journal of Language and Literature, Undiksha, Vol. 2, Issue. 3 (Page: 125 - 133).

Brown, H. D. 2007. Teaching by Principles: An Interactive Approach to Language Pedagogy. (2nd ed.). New York: Longman. (Page: 1-80)

Cronsberry, J.. 2004. Word Walls a Support for Literacy in Secondary

School Classroom. Canada: Curriculum Services. (Page: 1 - 20)

Dalman. 2014. KeterampilanMenulis. Jakarta: Rajawali Pers. (Page: 1-15). 
Fauzi, A. 2017.The Effect of Edmodoo on Students' Writing Skill in Recount Text". IJPTE: Volume 1, Issue 2. (Page: 73 - 79)

Fauziati, E. 2015.Teaching English as a Foreign Language. Surakarta: Era PustakaUtama. (Page: 120 - 124).

Green, 1993.Teaching Vocabulary with Word Wall. New York: Pippin Publishing Corporation. (Page: 1-2)

Indrayana, I D.G.A. 2014. The Use OfWord Wall Game To Teach Writing Skill Of The Eighth Grade Students Of SMPN 2 Blahbatuh in

Academic Year 2013/2014. The First Advisor: Dr. Drs. I Made

Sukamerta, M.Pd and the Second Advisor: I GustiAgungPutriWirastuti,S.S,. M.Hum. (Page: $2-15$ )

Jasmine, J. \& Pamela S. 2009. The Effects of Word Walls and Word Wall Activities on the Reading Fluency of First Grade Students. Reading Horizons, Volume 49, Issue 4, Article 5. (Page: 1 - 15)

Jerry. 2010. Instructional Strategy Teaching Word Wall. New York: Houghton Mifflin Company. (Page: $10-20$ )

Kasim, N. A. 2013. Increasing the Students' Vocabulary Mastery by Using Word Wall Media. Jakarta: RinekaCipta. (Page: $20-22$ ).

Khotimah, K. \&Kartika C. S. 2016.AnalisisKesulitanMenulisKaranganPadaSiswaKelasIvSdn 2 Panjer. Surabaya:UniversitasSebelasMaret. (Page: 495 - 498)

Kurniasih, W., dkk. 2015. The Use of Word Wall Media in Teaching Descriptive Writing. English Education Program FKIP Untan, Pontianak. (Page: 1 - 30)

McCarthy, M. 2018. The world's Most Spoken Languages. Retrieved from Statista: https://www.statista.com.

Nunan, D. 1989. Designing task for the communicative classroom. Cambridge: Cambridge University Press. (Page: 70-74)

Nordquist, R. 2017. English as a Foreign Language (EFL). Retrieved from ThoughtCo.: https://www.thoughtco.com.

Oshima, A. \& Ann H. 1983.Writing Academic English. Melbourne: Addison Wesley Publishing Company. (Page: $1-80$ )

$\mathrm{Oz}, \mathrm{H}$. 2006. Investigating the relationship between foreign language learning and call attitudes among EFL freshmen students. Procedia - Social and Behavioral Sciences 176. Elsevier Ltd. (Page: 250 - 255).

Pallant, J. 2016. SPSS Survival Manual: A Step by Step Guide to Data Analysis Using SPSS Program (6th Edition). London: McGraw-Hill Education. (Page: 23). 
Paramartha, AAGY. 2012. The Effect Of Self-Assessment Strategy And Self-Efficacy On Students' Writing Competency. International Journal of Language and Literature, Undiksha, Vol. 1, Issue 1 (Page: 1 - 15).

Rossum, E. J., and Hamer, R. 2010. The Meaning of Learning and Knowing. Rotterdam: Sense. (Page: 11)

Sari, R.A. \&Diah P. S. 2015.The Making of Word Wall to Improve Elementary School Students English Vocabulary.PolitenikNegeriBengkalis: JurnallmiahMahasiswa, Volume 4. (Page: 28 - 30).

Southerland, L.2011. The Effect of Using Interactive Word Wall to Teach Vocabulary to Middle School students, University of Florida (UNF) Theses and Dissertation paper 390. (Page: $70-89$ ).

Susanto, A. 2015.TeoriBelajar\&Pembelajaran di SekolahDasar. Jakarta: Kencana. (Page: $230-148)$.

Sugiyono. 2011. MetodePenelitianKuantitatif, Kualitatif, dan R \& D. Cetakanke 7. Bandung: Alfabeta. (Page: 1-80).

Tuckman, B. W. 1999. Conducting Educational Research: Fifth Edition. Ohio: Harcourt Brace College. (Page: 93 - 259).

Widikasih, N. K. 2008. An experimental study on the effect of word wall technique combined with colorful pictures on students' vocabulary mastery of the first grade students of SMP Lab Undiksha, Singaraja. E-Journal UniversitasPendidikanGanesha. (Page: 10 14).

Yarger, N. 2016.5 Benefits of Learning English. Retrieved from LTC eastbourne: http://ltcenglish.com/.

Yunus, M. Md. dkk. 2018. Students' Awareness and Perceptions towards "Pre-Writing Stage" as a Strategy in Writing Directed Essay. CreativeEducation, 9. (Page: 2215-2223).

Zhang, Y. 2019. The Effect of Metaphorical Competence on Students' Writing Skills. Creative Education , 10.(Page: 151 - 155). 